\title{
The Interaction of Code-switching and EFL Teachers' Perceptions on their Teacher Identity Development
}

\author{
Suna Altun* \\ Yeditepe University, Graduate School of Educational Sciences, English Language Teaching PhD Program, Kaylşdağ Cad. 34755 , \\ Istanbul, Turkey
}

Corresponding Author: Suna Altun, E-mail: snaaltn@gmail.com

\author{
ARTICLE INFO \\ Article history \\ Received: October 14, 2018 \\ Accepted: January 07, 2019 \\ Published: February 28, 2019 \\ Volume: 10 Issue: 1 \\ Advance access: January 2019 \\ Conflicts of interest: None \\ Funding: None \\ Key words: \\ Pre-service English Language Teacher, \\ Code-switching, \\ Identity Development, \\ Perceptions, \\ Past Experiences, \\ Language Choice, \\ Feelings
}

\begin{abstract}
This study aimed to explore pre-service English language teachers` perceptions of code-switching (CS) in language classrooms and how their perceptions affect their teacher identity development. Three pre-service teachers from a private university in Istanbul, Turkey participated in the study. The data were collected through semi-structured individual interviews and graphic elicitation tasks. The data were analyzed and codes were obtained, which later on provided three main themes: the effect of past experiences, perceptions towards CS, and identity development. It was discussed that the pre-service teachers' past language learning experiences influenced their CS perception both of which in turn affected their identity as self and the practice they demonstrated as language pre-service teachers. It is implied that pre-service teachers' identity development together with influencing factors such as language choice in EFL classrooms can be incorporated into the teacher education programs.
\end{abstract}

\section{INTRODUCTION}

Teacher identity shows how teachers perceive themselves as professionals. As well as affecting their professional success, teacher identity also has a big influence on their feelings as teachers in classroom and school environment (Lerseth, 2013, p. 13). There are two important points related to the teacher identity development: "Who a teacher is and what a teacher does" (Beijaard, Meijer \&Verloop, 2004; Gee, 2000; Moje\& Luke, 2009). Furthermore, Lerseth (2013) suggests some circumstances that she thinks influence the development of above mentioned two important points. These circumstances are identity being a continuing process, various identities that teachers possess, it's being recognized by the others and its development via social channels (Lerseth, 2013, p. 28).

Code-switching (CS) is changing between languages in the same discourse in bilingual or multilingual environments (Numan and Carter, 2011). It is a concept that is handled in bilingual or multilingual settings, and foreign language (FL) classrooms are among these bilingual or multilingual settings. According to Sert (2005), FL teachers may code-switch either consciously or unconsciously and there have been debates over the effect of this conscious or unconscious practice in FL classrooms. While the traditional only-L2-use opponents state that it may cause students to use the target language improperly, L1-use supporters in foreign language classrooms think that it may be beneficial to the students (Bensen \& Çavuşoğlu, 2013).

There are separate studies which have explored foreign language teachers ' and pre-service teachers' identity development and their perceptions towards CS in FL classrooms. The literature on teachers' perceptions towards CS in FL classrooms and their identity development that is to be handled in depth in the following section shows that these two topics share some important aspects such as experience, teachers' feelings and self-perception as a teacher like being successful or unsuccessful; or to have sufficient knowledge of the subject or vice versa.

Despite sharing common concepts, to the researcher's knowledge, there is almost no study that incorporates EFL teachers or pre-service teachers' perceptions towards CS and its relationship with their identity development. Based on 
this gap, the present study attempts to investigate pre-service English language teachers' perceptions of code-switching and how these perceptions affect their teacher identity development. The justification of the research relies on the assumption that these two distinct topics, foreign language teachers' perceptions of CS and their identity development are closely associated with teachers' classroom practice and the former one has an effect on the latter one.

Taking the relationship between code-switching and teacher identity development, as well as the gap in the literature, it is aimed in this study to find answers to the following research questions:

- What are the perceptions of pre-service English teachers about the code-switching?

- How do the perceptions of pre-service English language teachers about code-switching affect the process of their identity formation as a teacher?

\section{Literature Review}

\section{Teacher's identity development}

Before entering a teacher education program, pre-service language teachers possess some beliefs and attitudes towards language learning and teaching based on their prior experience. These beliefs and attitudes are brought to teacher education programs and impact it. However, Clarke (2008) points out that these beliefs may change because of the teacher education program. This assumption is based on his study (Clarke, 2008) in which he revealed that the beliefs of student teachers in the United Arab Emirates about reading were impacted by their past learning experiences. However, these beliefs were changed after the training received in teacher education program.

Fleming et al. (2011) also examined the beliefs brought to English as a Second Language (ESL) teacher education program by pre-service teachers and how they dealt with these beliefs during the education. Similar to Clarke (2008), they also found that these previous beliefs shifted after they had finished the language education program. For instance, one participant in this study believed before the program that the best way to learn English as a second language was to immerse English learners with other students who were speaking English as a first language. However at the end of the program, this belief changed and the pre-service teacher learned that students could get benefit of their mother tongues while acquiring a second language. On the other hand, both studies showed that there may be some previous beliefs which resist changing in spite of the teacher education programs.

A further study was conducted by Lerseth (2013) related to the factors that shape the pre-service teacher's identity development. Upon analysing the data collected from four pre-service teachers, eight main factors influencing pre-service teacher identity development were obtained. These factors were "students' past experiences, mentor and teachers' impact, students' self-awareness of identity, students' knowledge about content, teaching pedagogy, teachers' attitudes, classroom management and a variety of tensions" (Lerseth, 2013, p. 121-122).
The studies conducted by Clarke (2008), Fleming et al. (2011) and Lerseth (2013) meets at a common point: students' past experiences about language learning have an important effect on their identity development as pre-service teachers. While some change after language teacher program, some remain unchanged or incorporate newly learned ideas.

\section{The perceptions towards CS or L1 use in EFL classrooms}

The studies show that there may be various factors that may affect teachers and student teachers' perceptions towards CS in the classroom. Experience, the factor that was found to affect pre-service teachers' identity development is a determining factor that influences pre-service teachers' perceptions towards CS in foreign language classrooms. In Macaro's(2001) study, it was a student teacher's own language learning experience that influenced her perceptions towards CS. The same factor is found in de la Campa and Nassaji (2009) who examined teachers' perceptions towards L1 use in foreign language classrooms. However different from Macaro's (2001) finding, experience in de la Campa and Nassaji (2009) was the teaching experience of the teachers that impacted on their perceptions. Likewise, in Kayaoğlu (2012) interviews revealed that while EFL teachers started to teach with the aim of using only L2, after becoming more experienced as a result of teaching many years, they saw no point in insisting on only L2. Their teaching experiences led them to hold positive beliefs towards the adoption of L1 because of its facilitative aspect in teaching "particularly grammar and vocabulary at early stages, giving comprehensible instructions and creating a supportive classroom environment" (p.33).

The feelings of teachers and student teachers are also among important findings of the studies regarding the perceptions of L1 use or CS in foreign language classrooms. In Macaro's (2001) study, one of the student teachers reported the feeling of conflict about using L1 in procedural instruction pointing out the reason of not being good enough in L2. In the same study, the other student teacher who was influenced by her own language learning experiences on the other hand, experienced almost no conflict concerning L1 use based on the reasons such as avoiding students' confusion and interaction problems. She further highlighted that, in order to maximise students' L2 use she did not use only L2, but did it through pair and group work activities (p.544). Moreover, the teachers in de la Campa and Nassaji's (2009) study who often resorted to L1, believed in the facilitative aspect in the use of L1 for important instructional purposes. In this study while the novice teachers' purpose of using L1 was a translation between L1 and L2 as a practical language strategy, the experienced teacher's aim of using L1 was to provide the students a safe environment. In Van der Meij and Zhao's (2010) study which investigated both students and teachers' perceptions towards CS, it was found that while teachers were not aware that they code-switched that much and long, they reported a feeling of comfort in doing so. Furthermore, in Cheng's (2013) study who examined the teachers' beliefs and attitudes towards code-switching in EFL classrooms in 
China, some teachers highlighted the advantage of L1 use for students' understanding and reported no feeling of guilt or being upset. In the same study on the other hand some other teachers reported the feeling of fear that L1 would hinder students' L2 acquisition process. They further reported feelings of guilt and discouragement for the they used L1. The feeling of embarrassment was also revealed by some teachers because of the reasons such as students' expectation of teachers to speak English, doubt about teachers' language proficiency, and the fear that students could be dependent on L1. An interesting finding in Cheng's (2013) study was that the teachers who had negative attitudes towards CS in English-Chinese bilingual classrooms practiced it frequently. Similar to Cheng (2013), Copland \&Neokleous (2010) who analysed the reason of L1 in EFL classrooms and feeling about it in Cyprioticcontext, observed contradiction between teachers' beliefs and their practices in the classrooms. The feelings such as guilt and self-reproach were reported by these teachers because of using L1 in EFL classrooms. Copland \&Neokleous' (2010) argued that incongruity between their beliefs of using only L2 in EFL classrooms and their practices of using L1 frequently in the classroom may be due to the feeling of guilt as they were trying to balance between pedagogical ideals and contextual realities (p.271).

\section{METHODS}

The participants of this study were three English Language Teaching (ELT) students who will be called with the first letter of their names: N, E and M. They were studying at a private university in Turkey two of whom were females and one of whom was male aged between 20-22 years old. They were all at the fourth year of their studies doing their practicum as pre-service teachers. Their first language was Turkish and they spoke English as a second language. According to Patton (1990), the samples in qualitative research are selected purposefully in order to select "information-rich cases for study in-depth (p.169). Thus, the participants who were voluntary to reflect on their experiences and express their feelings and thoughts were selected purposefully for this study.

According to Rubin \& Rubin (2005) semi-structured individual interviews give the interviewer the opportunity to examine and elaborate on interviewee's answers which facilitates "depth to be achieved" (p.88). Furthermore, Bagnoli (2009) states that graphic elicitation tasks enable people to be able to think beyond the verbal thinking which would enhance the inclusion of much more experience that could be ignored in verbal thinking (p.565-66).Thus, semi-structured individual interview and graphic elicitation were used to collect the data for this study. Each interview together with graphic elicitation lasted about 40 minutes. The interviews were recorded and later transcribed. After the graphic elicitation task, the participants were asked what they meant by the drawings and their explanations were also noted down. The questions of the interview were about English learning experiences especially in speaking skill, the use of spoken language and code-switching in ELT courses, their perceptions about code-switching and relationship between the code-switching and their identity development as English pre-service teachers. The graphic elicitation also focused on their perceptions on code-switching as ELT students and prospective teachers (See Appendix A, B, C).

The transcribed data of the interview were analysed through the content analysis and initial coding method. According to Saldaña (2009), initial coding is an opportunity "for the researcher to reflect deeply on the content nuances of the data" (p.81). Through the content analysis, the whole data were read in order to get a general idea. Afterwards, a second reading was done in order to obtain the codes. Furthermore, the drawings that were obtained through graphic elicitation tasks and the interpretations of participants about their drawings were analysed and incorporated into the interview data. In coding process, based on Saldaña's (2009) suggestion for initial coding, the data were separated into parts, scrutinized closely and differences and similarities were compared (p. 81). After the coding process, a codebook was developed (See Appendix E). The codebook involved the name of the code based on the Initial coding, the definition of the code, inclusion and exclusion criteria and examples for each code from the data. Table 1 shows an example from the codebook that I developed:

The development of a codebook allowed me to move on to the next step which is categorizing the codes under three main themes. Themes can be defined as more abstract categories under which codes that are derived from images and expressions are grouped (Ryan \& Bernard, 2003).

In order to ensure the trustworthiness of the data collection and analysis, the triangulation strategy was adopted. This strategy encompasses multiple sources of data (Rossman \& Rallis, 2011). The multiple sources of data in this study include the individual interviews and graphic elicitation tasks. Furthermore member checking strategy was used in graphic elicitation task to be able to interpret the message by the participant appropriately.

In order to deal with the researcher's biases and preconceptions, bracketing was employed. This method is adopted in qualitative research with the purpose of avoiding involvement of researcher's preconceptions, previous theories or assumptions that may affect the research process with an undesirable quality (Bertelsen 2005; Tufford $\&$ Newman 2012). For instance, before the interview I had preconceived that the English Language Teaching (ELT) Department lecturers code-switched a lot and this somehow affected students' identity development as English pre-service teachers. At the beginning of my first interview, I realized that I was trying to lead the interviewee to answer in compliance with this preconception. After having realized it, I bracketed myselfby not leading interviewees to answer in a certain way. Furthermore, after the first interview, I reflected on my bracketing experience in the analytic memo. According to Saldaña (2009) analytic memo is "a place to "dump your brain" about the participants, phenomenon, or process under investigation by thinking and thus writing and thus thinking even more about them" (p. 32). Thinking about my preconceptions and later my overcoming efforts through bracketing in my 
Table 1. A part of codebook developed for present study

\begin{tabular}{llll}
\hline Code & Definition & Inclusion/Exclusion criteria & Example from the text \\
\hline $\begin{array}{l}\text { Classroom } \\
\text { as the only }\end{array}$ & When these pre-service & Includes EFL setting & N, I didn't have any \\
place to & teachers were EFL students, & Excludes ELT settings & English out of my classroom. \\
practice & they could practice English & & \\
English & only in the classroom & & \\
\hline
\end{tabular}

first analytic memo helped me be more careful in the next two interviews.

\section{FINDINGS}

This paper attempts to investigate the perceptions of pre-service teachers about code-switching (CS) in EFL and ELT classrooms and how these perceptions affect their identity development as an English pre-service teacher. The data collected through semi-structured individual interviews and graphic elicitation with three participants, N, M and E, was coded and categorized under three main themes: (1) the effect of past experiences (2) perceptions towards CS and (3) identity development.

\section{The Effect of Past Experiences}

The analysed data revealed that there is an effect of pre-service teachers' past experiences on the perceptions towards L1 or L2 language use in EFL classrooms and identity development as pre-service teachers. The codes that fall under this category are: Classroom as the only place to practice English, language choice by teacher in EFL classrooms and oral use of English in the classroom. All interviewees pointed out that the classroom was the only place to practice English when they were EFL students. With regard to this code, $\mathrm{N}$ stated that "I didn't have any opportunity to practice English out of my classroom". In line with her language learning experience, related to the question whether she should use L1 in EFL classrooms, $\mathrm{N}$ maintained that ".... The only opportunity to talk in English is classroom so they need to talk in English and they expect you to talk in English more". Furthermore, M pointed out that "Out of classroom? No, it was only in the classroom... even though today we can use internet to talk, it is still important that we use English in the classroom".

A further topic mentioned frequently by the participants was language choice in EFL classrooms. While talking about their learning background, the students mentioned whether their teachers used first language (L1) or target language (L2) in English language classrooms. E pointed out "In my time they used their mother tongue in the classroom as well, especially explaining some certain information about lesson". M further mentioned the following:

....in the primary school, the commands given by the teachers like "Be quiet or sit down" were in English. But as far as I remember there were Turkish explanations for some words, for some sentence structures...but then when I passed from elementary school to middle school, it became more primarily English.
A final code that is handled under this theme is the oral use of English in the classroom. Based on the questions directed to the participants, they gave information about how they used English orally in the classroom. Related to this issue E said the following: "There were role-pays in the classroom. We acted as an actress or actor. Or we worked as a group, so we used English in this way". Another example is about N's experience of oral use of English in the classroom. She stated that "There were native speakers. We could talk to them in English. We made practice orally". While stating that the classrooms were the only place to practice English, related to this code M emphasized that there weren't actually many opportunities to practice English orally in the classroom as the students were not proficient enough and he was the only one who was really trying to speak in English in the classroom.

\section{Perceptions Towards CS}

All the interviewees talked about their perceptions of CS very frequently. Each of them revealed different views about it. The codes analysed under this theme are the reasons of CS in participants' opinions and their feelings towards it. They are: reason- slip of the tongue, reason- emphasizing a point, reason- lack of proficiency, reason-making students understand, feeling-neutrality and feeling- relief.

$\mathrm{M}$ who possessed negative perceptions towards CS mainly focused on the reasons like, slip of the tongue and lack of proficiency. In reference to the reason-slip of the tongue he said the following:

...if we hear one word from the person who said no Turkish in the classroom say something in Turkish by accident or whatever, I think it would not be good just as I said before. If you have rules, you have to follow it no matter what. So except from the accidents I mentioned it would be bad if the teacher would have slip of the tongue moments actually.

He further proposed the lack of faculty as a reason of CS by saying "Actually one of the reasons for CS is lack of faculty". M's negative perceptions towards CS can be further seen in the drawings that he did in graphic elicitation task. He was asked to draw about his feelings when his professor switched between languages in ELT classrooms. He drew some students on the one side and himself alone on the other side far from the rest. When I asked him to explain the drawing, he said that while the professor was spending too much time to CS in order to explain the topic to the other students, he had already grasped the topic and looking beyond the other students. So, he does not need CS by teacher to understand the content of the lesson.

Another reason proposed for CS was lack of proficiency. This reason was mentioned by both $\mathrm{N}$ and $\mathrm{M}$. $\mathrm{N}$ said the following: 
...assuming that I am speaking in English and I code switch to Turkish, I may feel that I am not good enough in English. For example I can say that why I cannot say this in English. I may have low self-esteem...

She further stated that "They can question my English knowledge" referring students in a more advanced level of EFL classrooms.

The reason-emphasizing a point was mentioned by all the interviewees. Related to it, M said; "I think they (professors) always CS when they want to emphasize a point." Another reason that all the interviewees agreed on was making students understand. For instance E said “ ... when students don't understand or when the lecturers think that students don't understand, they code-switch".

The interviewees also revealed their feelings about CS. For example E said; "When they code switch I feel relieved in some issues...For example in literature classroom, teacher code switches about a literary term...".E's positive feelings were revealed in the graphic elicitation task as well. She drew an ELT classroom setting where the professor was code-switching. While the other students were bored with it, she showed happiness in the drawing by writing in the bubble "There are beneficial writings for me".

Lastly, N expressed neutrality by saying; "I don't think it is so much importance when they sometimes introduce Turkish in an English sentence. They can do that. I don't think something negative or positive. I am neutral". In the graphic elicitation task on the other hand she pointed out the length of CS. She drew a right angle whose sides represented time and anger. She explained that she got annoyed when the lecturer kept CS too long.

\section{Identity Development}

The last theme was identity development and the codes categorized under this theme were: the effect of professors and who an English teacher is, self-perception as a pre-service English teacher and language choice in student teachers' classrooms.

The code effect of professors was mentioned by three of the participants. Both $\mathrm{M}$ and $\mathrm{N}$ pointed out that they idealize their professors at the university and they affected their way of teaching. For example N said, "You know we idealize our lecturers at the university, because it is the last step before we become a teacher". Furthermore, they mentioned the effect of language use by the professors. For example E said; "...it affects me when I see a lecturer code switch, there is no problem. I can use it as well". She further showed in her graphic elicitation task that when she becomes a teacher she would CS in the classroom for the benefit of the students.

Related to both idealizing the professor and effect of language use by the professor $\mathrm{M}$ said the following:

...the use of L1 by my teachers gave me a more relaxed attitude I think regarding the use of L1 and L2 in classrooms. But when I went to college and saw the teachers' attitudes using no Turkish, I got a perception that maybe I shouldn't be so relaxed. I think the use of Turkish affects my perceptions. The teacher in my mind, the ideal teacher becomes a more relaxed person...
Language choice in student teachers' classrooms was another code discussed under the theme of identity development. This code was extracted from drawings by participants in the graphic elicitation task. They were asked to draw themselves as English teachers and importance of language choice in their classrooms. Drawing a teacher who code switched between English and Turkish, E stated that she code switched in order to clarify the topic for students, to avoid confusion in students' minds and help them understand. M, on the other hand, drew a very long road and a door at the end of the road. He explained that, "It is a very long way for students to learn the language and as a teacher I should be the door who let them pass the door to the world of target language". He further stated that as a teacher he was the one who allowed the students to pass the door to accomplish in EFL pointing out that; "Not speaking in English means shutting the door to the students". Lastly, N drew geometrical shapes and explained that the choice of language was very important. She stated that, "The importance of language choice, which should be English, goes beyond the teacher and the students in the classroom". Thus it can be said that while E would include Turkish in her classrooms by code switching between Turkish and English, $\mathrm{M}$ and $\mathrm{N}$, on the other hand, would avoid Turkish, so CS in their classrooms.

Another code dealt under this theme was who an English teacher is which is inferred from student teachers' answers to the question "Who is an English teacher?" In regards with it, M said; "...first you have to master English...you also have to take courses and make research on your own, let's say pedagogy about how to teach". $\mathrm{N}$ answered to the same question as following:

...is not the one who just knows the language. He needs to know the culture, pragmatic knowledge.when to use what. our material is language, so we use it to communicate. So the teacher has to have good communicative skills besides having English language knowledge.

It is seen that similar to $\mathrm{M}, \mathrm{N}$ highlighted having good communicative skills and English knowledge for an English teacher. Different from M and N, E did not emphasize good English or communicative knowledge, stating that:

They should fulfil students' needs, interests. An English teacher should be well-prepared before coming to the classroom, should be innovative in lesson.should know all things related with life. In Turkey every student, every person approaches the teacher "you know everything, Ok, you are teacher you should know everything. It is not a good definition.nobody knows everything. But we should be professional at our field; we should improve ourselves as well.

The last code categorized under this theme was self-perception as a/n (pre-service) English teacher. This includes participants' both own practices and perceptions as English pre-service teachers and the English teacher they would like to be in the future. Concerning it E pointed out that:

When I become a teacher in the future, maybe I want the students ask questions all the time, they should be incurious. to make lessons interactive, I make them groups, I try to make them interact, to interact with each other by using groups works, pair works, or dramas. 
N's statements related to the same code were as following: I need to be sufficient not just in the language, but in teaching qualities. I need to be practical....actually I think every English teacher can teach English just talking English. $80 \%$ of the message is conveyed in English. So we can do this just talking in English. And with time the students will come along and they will learn how to understand. They will learn English at the end.

Furthermore, M stated that; "I am supposed to be the master of English. I think I have American accent. I am happy with that actually". It is seen that while pronunciation or speaking skills is highlighted by $\mathrm{M}$ and $\mathrm{N}$ under this issue, $\mathrm{E}$ stresses other characteristics of herself as a(n) (pre-service) English teacher.

\section{DISCUSSION}

\section{Student $M$}

Concerning the first research question of this study, it could be seen that $\mathrm{M}$ holds negative perceptions towards CS in FL classrooms. He attributed CS to the negative reasons such as slip of the tongue, lack of proficiency, and lack of faculty. This finding is in agreement with Macaro's (2001) finding in which the student teacher held negative beliefs towards using L1 in foreign language classrooms stating its reason as not being good at FL. It also shows consistency with the reason of doubt about teacher's language proficiency, which was stated by some teachers in Cheng's (2013) study. Furthermore, M's negative perceptions towards L1 use can be attributed to the teaching experience factor argued in Kayaoğlu's (2012) study which found that after having gained experience the EFL teachers benefited the use of L1 in the classrooms unlike their persistence of L2 use only in first years of teaching. Similar to the teachers in Kayaoğlu's study, M may have negative perceptions towards L1 use because of not being experienced in teaching yet.

With regard to the second research question of the present study, it could be argued that M's negative perceptions towards CS affect his identity development as a pre-service teacher on different aspects. Both his past experiences and his perceptions towards CS, which is also influenced by his past experiences, affect his identity development. Effect of past experiences on identity development confirms the argument by Lerseth (2013) according to whom, past experiences is one of the factors that influences identity development of the pre-service teacher. What is new is that perceptions towards $\mathrm{CS}$ and together with past experiences influences identity development. Another aspect is the effect of professors at the ELT department related to CS use in the classroom. M's statement that being affected by his professors who code switched in the classroom is in line with Clarke's (2008) arguments who pointed out that previous beliefs based on past experience can change with the teacher education program. However, later being affected by his mentor teacher who did not code switch in her classrooms is in line with Lerseth's (2013) argument that identity development is a continuing process. Experiences in a (pre-service) teacher can influence as well as influenced by this continuing process. It can be argued that in M's case while his past experiences caused negative perceptions towards code-switching in EFL classrooms (Lerseth, 2013), not being experienced in teaching consolidates these perceptions.

The metaphor used by $\mathrm{M}$ that he would shut the door if he did not use only English in the classroom supports the argument that what a teacher does is also related with identity development (Beijaard et al., 2000). In M's case, using only L2 and excluding L1, so the CS is an important practice in his classroom and it is closely related with his identity development as a pre-service teacher. Lastly, his self-perceptions as having good English speaking skills and possessing an American accent is related with who the teacher is which was argued to be interrelated with identity development by Gee (2000-2001). As an answer to who the teacher is M presents himself as the English teacher who does not need $\mathrm{CS}$ in the classroom. Thus, it can be argued that CS is related to who a teacher is and it affects the English pre-service teacher's identity development in this way.

\section{Student $E$}

Relating to the first question of this research, unlike $\mathrm{M}, \mathrm{E}$ holds positive perceptions towards CS in EFL classrooms. Pointing out the feeling of relief and beneficial aspects of CS to avoid incomprehensibility, E's positive perception is in line with the study by Macaro (2001) in which one of the student teachers showed positive attitudes based on the reasons of overcoming confusion and interaction problems. The finding also shows congruency with the perceptions of teachers in de la Campa \& Nassaji's (2009) study in which the facilitative role of CS for instructional aims were highlighted. Furthermore, it is also consistent with one of the findings of Cheng's (2013) study in which the help of L1 for students' comprehension was highlighted.

With regard to the second question of this study, it is seen that there is a relationship between E's positive perceptions towards CS and her identity development as a pre-service English teacher. Like other participants she expressed that the classroom was the only place to practice English and her teachers used both L1 and L2 in the classroom. Nevertheless, she favoured the adoption of L1 in EFL classrooms. This is because of her positive perceptions towards CS which is affected by her past experiences. When she was an EFL learner, E had positive experiences with CS which led to the feeling of relief and avoided confusion and as a pre service EFL teacher she expressed that she would code switch to clarify the topic and avoid confusion among students, a finding that is in consistence with de la Campa and Nassaji's (2009) and Van der Meij and Zhao's (2010) in which the facilitative aspect of code-switching and feeling of comfort were highlighted by the teachers. It is also congruent with previous studies that past experience is a factor on pre-service teacher's identity development (Clarke 2008; Fleming et al. 2011; Lerseth 2013).

In her answer to the question who an English teacher is, unlike other participants, E does not highlight either English speaking skills or to be master of English. Furthermore, while describing herself as an English teacher in the future, 
her statements such as to create an interactive classroom through dramas and group and pair works is an example of what a teacher does which is according to Beijaard et al. (2000) related to teacher identity development. It is worth highlighting here that E who favours CS in the EFL classroom mentioned that when she was an EFL student, the oral use of English was through role-plays, group and pair work. Thus, unlike $\mathrm{M}$ she does not think that the use of CS she would hinder students' progress in English. This finding contradicts with the finding in Cheng's (2013) in which some of the teachers held the concerns that CS would lead the students to be dependent on L1. However, it is in line with the pre-service teacher Macaro's (2001) study who held positive beliefs towards CS in FL classroom and in order to provide students use L2, adopted pair and group work activities instead of using only L2 with them.

\section{Student $N$}

While N states overtly that she is neutral towards CS in EFL classrooms, the feeling of not being proficient in English while code switching shows some negativity towards it. The concern of not being good in English when code-switching is in line the studies by Macaro (2001) and Cheng (2013) in which not being good at English or doubt about teacher's language proficiency were mentioned in relation with CS. Furthermore, in a graphic elicitation task the feeling of annoyance when adopted very frequently by the teacher demonstrates that even if she is neutral towards it, too much CS may lead to negative perceptions. While the finding of neutral perception does not show any similarity with the ones in the literature, a feeling of annoyance when it is repeatedly adopted may be related with her past experience as a language learner, which is an argument highlighted by Macaro (2001). Like other participants, $N$ expressed that the classroom was the only place to practice English orally and only with the native English speakers they had opportunity to do it. Thus, it can be discussed that she thinks that too much CS would restrain oral practice in English in the classroom which is the only place they could practice it, an argument in line with Cheng's (2013) finding that teachers did not use CS with the fear of students being dependent on L1.

Her perception towards CS is in line with her descriptions of who a teacher is and what a teacher does (Beijaard et al. 2000; Gee 2000-2001). While talking about language choice in her classrooms when she becomes an English teacher, she expresses that English language use is the most important aspect, thus she would use only English. This could be related to her past language learning experiences that classrooms were the only opportunity for her to practice English orally. As stated above this finding is congruent with arguments by the previous research in which it is argued that past experience has an effect on identity development (Clarke 2008; Fleming et al. 2011; Lerseth 2013). While talking about the ideal English teacher she would like to be in the future, emphasizing talking in English is also related to her past experiences of language learning and perceptions towards CS which is also shaped by her past experiences.

\section{CONCLUSION}

This study aimed to explore the perceptions of pre-service English teachers about code-switching in EFL classrooms and the effect of these perceptions on their teacher identity development. Based on these aims, data were collected from three pre-service EFL teachers through semi-structured interviews and graphic elicitation tasks were analyzed and coded which provided three main themes: the effect of past experiences (2) perceptions towards CS and (3) identity development. It was discussed in compliance with previous studies and theoretical background presented in the study that the pre-service teachers past language learning experience affected their identity development. Furthermore, their CS perceptions also influenced significantly their identity as self and the practice they demonstrate as language teachers.

Apart from these findings, their inclination of using either L1 or L2 is also found to be related to their past learning experiences which are similarly linked to their identity development as language teachers. As an implication for the field identity development of teachers together with their perceptions could be discussed as a part of teacher education classes of pre-service teachers.

As a suggestion for the future studies, I recommend the conduction of further studies about the pre-service teachers' choices of language use in the classrooms and its effect on their identity development.

\section{REFERENCES}

Bagnoli, A. (2009). Beyond the standard interview: The use of graphic elicitation and arts-based methods. Qualitative research, 9(5), 547-570.

Beijaard, D., Verloop, N., \&Vermunt, J. D. (2000). Teachers' perceptions of professional identity: An exploratory study from a personal knowledge perspective. Teaching and teacher education, 16(7), 749-764.

Beijaard, D., Meijer, P. C., \&Verloop, N. (2004).Reconsidering research on teachers' professional identity. Teaching and teacher education, 20(2), 107-128.

Bensen, H., \&Çavuşoğlu, Ç. (2013). Reasons For The Teachers'uses Of Code-Switching In Adult Efl Classrooms. Hasan Ali YücelEğitimFakültesiDergisi, 10(2), 69-82.

Bertelsen, P. (2005). Free Will. Consciousness and Self: Anthropological Perspectives on Psychology.

Cheng, X. (2013). Research on Chinese College English Teachers' Classroom Code-switching: Beliefs and Attitudes. Journal of Language Teaching \& Research, 4(6).

Clarke, M. (2008). Language teacher identities: Co-constructing discourse and community. Multilingual Matters.

Copland, F., \&Neokleous, G. (2010). L1 to teach L2: Complexities and contradictions. ELTjournal, 65(3), 270-280.

De la Campa, J. C., \&Nassaji, H. (2009).The amount, purpose, and reasons for using L1 in L2 classrooms. Foreign Language Annals, 42(4), 742-759.

Fleming, D., Bangou, F., \&Fellus, O. (2011).ESL teacher-candidates' beliefs about language. TESL Canada Journal, 29(1), 39-56. 
Gee, J. P. (2000). Identity as an analytic lens for research in education. Review of research in education, 25, 99-125.

Kayaoğlu, M. N. (2012). The use of mother tongue in foreign language teaching from teachers ${ }^{\text {ee }}$ practice and perspective. PamukkaleÜniversitesiEğitimFakültesiDergisi, 32(2), 25-35.

Lerseth, K. A. (2013). Identity development among pre-service teacher candidates.

Macaro, E. (2001). Analysing student teachers' codeswitching in foreign language classrooms: Theories and decision making. The Modern Language Journal, 85(4), 531-548.

Moje, E. B., \& Luke, A. (2009). Literacy and identity: Examining the metaphors in history and contemporary research. Reading Research Quarterly, 44(4), 415-437.

Numan, D. \& Carter, D. (2001).Teaching English to speakers of other languages.cambridge: Cambridge University Press
Patton, M. Q. (1990). Qualitative evaluation and research methods. SAGE Publications, inc.

Rossman, G. B., \& Rallis, S. F. (2011). Learning in the field: An introduction to qualitative research. Sage.

Rubin, H. J., \& Rubin, I. S. (2005).Structuring the interview. Qualitative interviewing: The art of hearing data, 2, 129-151

Ryan, G. W., \& Bernard, H. R. (2003). Techniques to identify themes. Field methods, 15(1), 85-109.

Saldana, J. (2009). An introduction to codes and coding. The coding manual for qualitative researchers, 1-31.

Sert, O. (2005). The Functions of Code-Switching in ELT Classrooms. Online Submission, 11(8).

Tufford, L., \& Newman, P. (2012).Bracketing in qualitative research. Qualitative social work, 11(1), 80-96.

Van der Meij, H., \& Zhao, X. (2010).Codeswitching in English courses in Chinese universities. The Modern Language Journal, 94(3), 396-411. 


\section{APPENDIX}

\section{A: Analytic Memo of Graphic Elicitation Task with N}

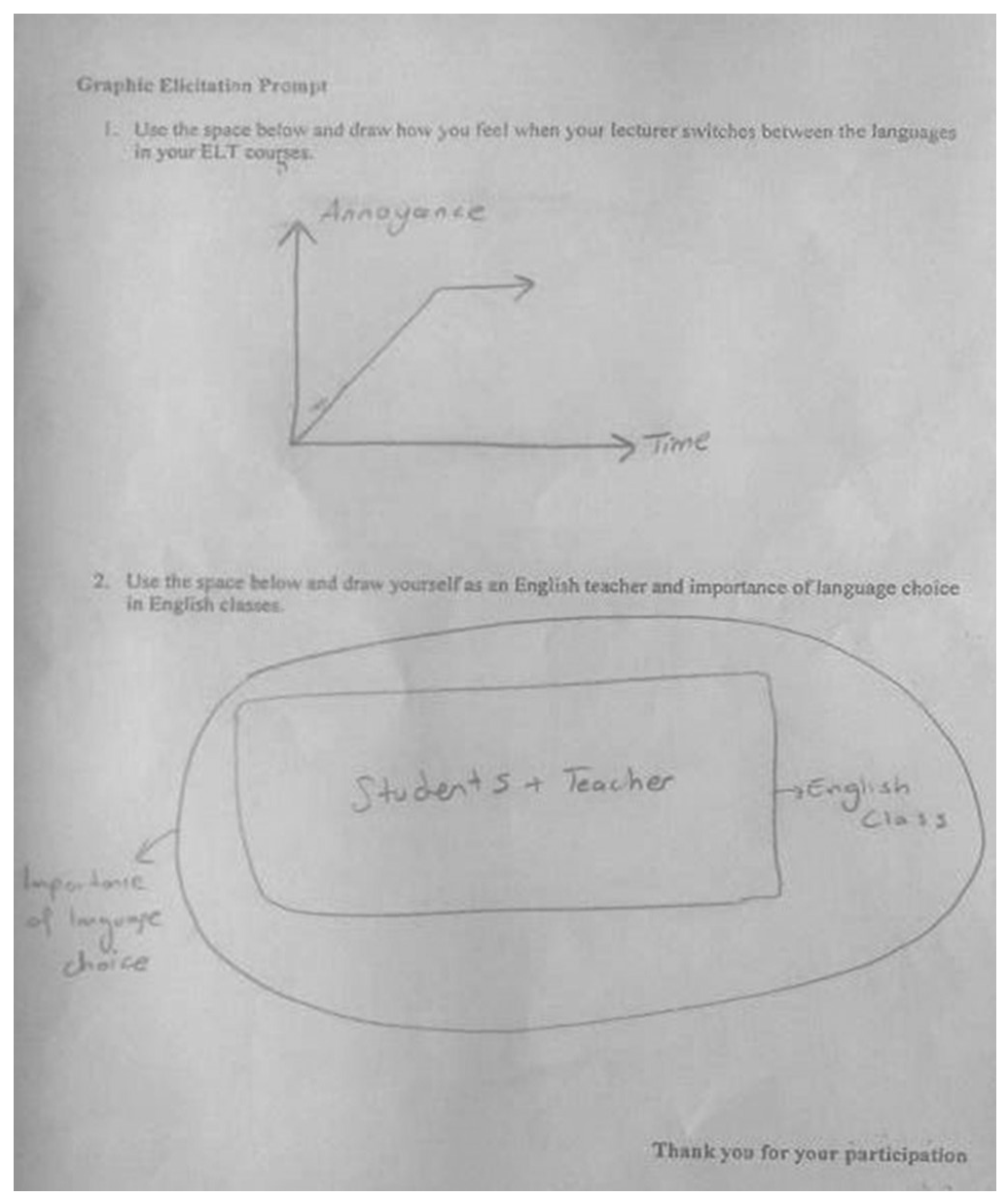

In the graphic elicitation task, I asked the participant, $\mathrm{N}$, to draw about her feelings when her lecturer switches between the languages in her ELT courses. I further asked her to draw herself as an English teacher and importance of language choice in English classes. The task was done six day after the interview. She was a bit surprised about the task. I think it is because she perceives the drawing task a childish task. Before starting drawing she was grumbling like "I am not good at drawing... The last time I drew was around 10 years ago..." Her reaction to the task did not surprise me as I gave the similar reactions when I was asked to draw in Qualitative Research Methods course. In order to encourage her to draw, I told her that she was free to draw in any form that she wanted.

Instead of drawing detailed and complex pictures she preferred to express herself with geometric shapes. Related to her feelings about her lecturers' code-switching, she drew a right angle. One of the sidesof the angle represents the time and the other side represents her annoyance. Between two sides there is a curve. At the first glance, I could not get the exact message she wanted to convey and asked her what she wanted to say by the drawing. She told me that her annoyance about code-switching by her lecturers increased parallel with the time. The curve's being constant after a time represents that she got used to the situation and does not get annoyed anymore. Comparing her expressions by the graphic with the interview, I can say that she was clearer in her drawings. While interviewing her, I did not get that she was that annoyed by the code-switching. In the second graphic, she drew a rectangle which represented English class and she wrote "students+teacher" in it. She also drew a big circle which embodied the rectangle and referred to the importance of language choice. She explained that the choice of language was very important and it included English class. We can infer that in her perception the importance of language choice goes beyond the teacher and the students in the classroom. The second drawing was more consistent with the answers she gave about the importance of language choice during the interview. 


\section{APPENDIX B: Analytic Memo of Graphic Elicitation Task with M}

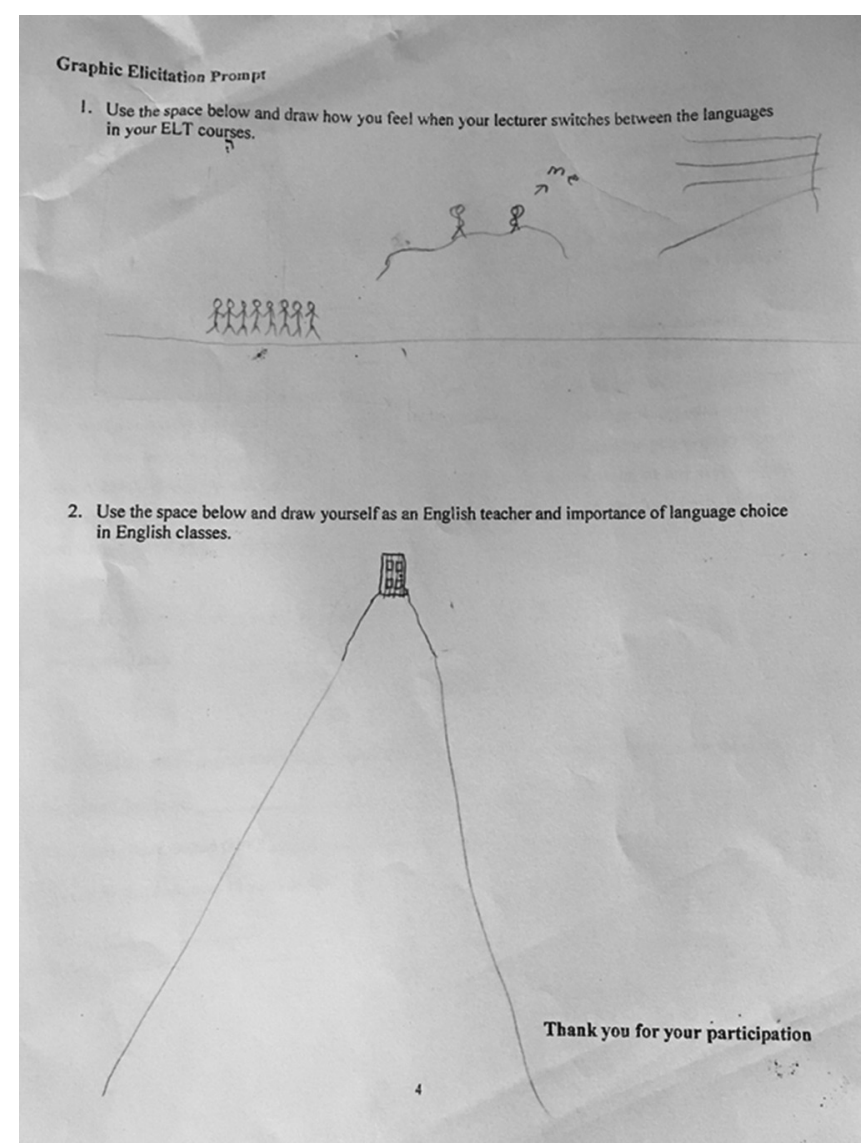

M was asked to do graphic elicitation task three days after the interview. The task consisted of two questions: The first one was about his feelings when his lecturers code-switched in the classroom and the other was about him as an English teacher and importance of language choice in English classes. He hesitated for some seconds when he was asked to draw, which was not surprising. As we discussed before, people think that the drawing was a childish task and also it had been so many years since the last time they drew. I told him that he was not expected to draw very well and he was free to draw the he wanted to. Thus he was convinced and he drew for two parts.

In the first part, he drew some students on one side and the lecturer in front of them making the lesson. There was one person who was on the other side of the teacher far from the other students. I did not understand the message he gave, so I asked him what he meant by the drawing. He told me that the students represented his classmates and the person that is on the other side of the teacher was him. He further told that while his lecturer was re-explaining something by code-switching, he had already grasped it unlike the other students. So, he did not need code-switching and he had a vision beyond his classmates.

In the second part, he drew a very long road and a door at the end of the road. He explained that, it was a very long way for students to learn the language and as a teacher he should be the door who let them pass the door to target language's world. He further stated that as a teacher he was the one who allowed the students to pass the door to accomplish in EFL. Not speaking in English would mean shitting the door to the students.

M's drawings were consistent with his statement during the interview. He consolidated his view about code-switching about which he has negative perceptions.

\section{APPENDIX C: Analytic Memo of Graphic Elicitation Task with E}

This task was done after the interview. There were two parts in graphic elicitation task. In the first part E, the interviewee, was asked to draw her feelings when her lecturer switches between Turkish and English in the classroom. The second part, on the other hand included a question to draw heras an English teacher and importance of language choice in English classes. Like N, E was also surprised by the task, but she was eager to draw.

In first part she drew a classroom setting where there were three students sitting on their desks. The first student in the drawing was angry and there was a bubble in which she said "Phh! It's boring". The second student represented E and she was happy and in the bubble she said "There are beneficial switches for me". The last student was sleeping. When I asked E to explain me the drawings, she told me that unlike the other students who found code-switching boring, she thought it was beneficial. 


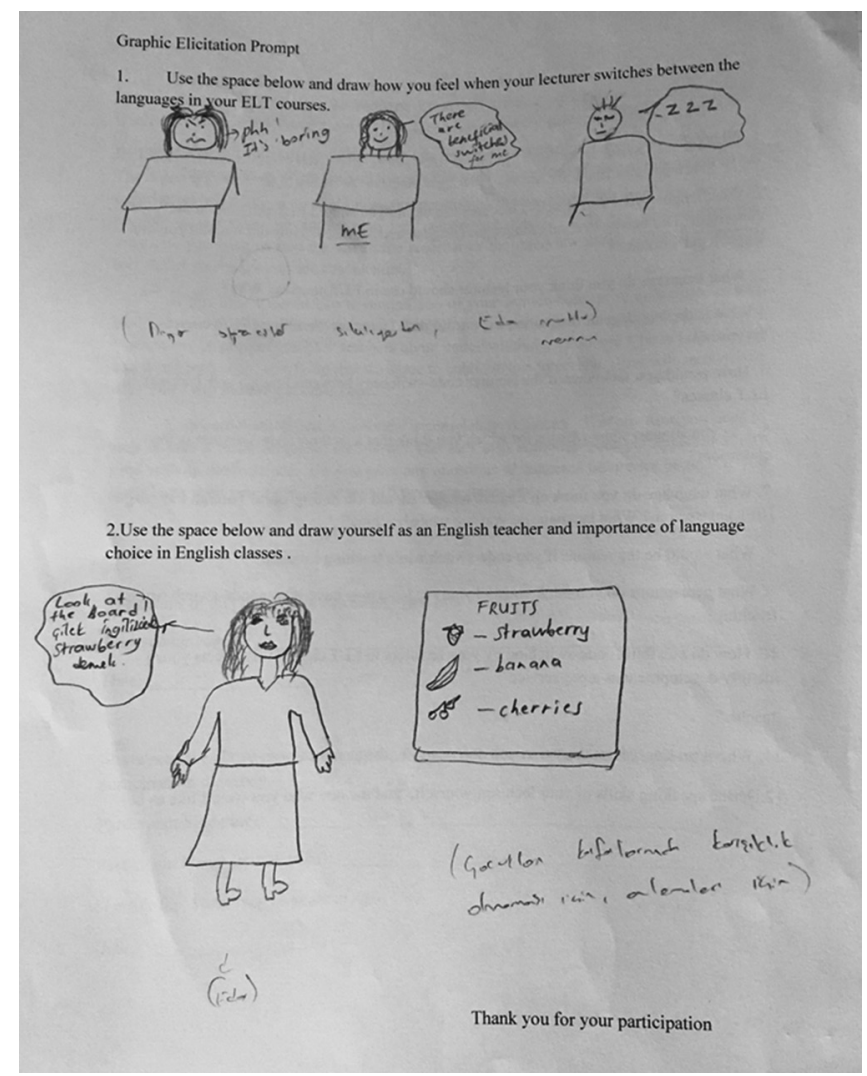

In the second part drew her and a board. On the board there were some pictures of fruits and their names in English. In the bubble, she code switched between Turkish and English to explain the meaning of strawberry. When I asked her what the picture meant, she explained that she code-switched between Turkish and English in order to clarify the topic for students, avoid confusion in students' minds and help them understand.

The task really helped me get E's opinion about my research. While interviewing, she was not sure about her perceptions. It is because she sometimes expressed inconsistent opinions. However the pictures she drew and the explanations she did after drawing made it clear that she finds code-switching beneficial and she would use it while teaching for the reasons mentioned above.

\section{APPENDIX D: Preliminary Codebook based on Data from M}

\begin{tabular}{|c|c|c|c|}
\hline Code & Definition & Inclusion/Exclusion Criteria & Example from the Text \\
\hline $\begin{array}{l}\text { Requirement } \\
\text { of speaking } \\
\text { English }\end{array}$ & $\begin{array}{l}\text { Speaking only } \\
\text { English in the } \\
\text { English classrooms. }\end{array}$ & $\begin{array}{l}\text { Includes the students and } \\
\text { classroom setting } \\
\text { Excludes teachers and the } \\
\text { setting out of the classroom }\end{array}$ & $\begin{array}{l}\text { p. } 2 \text { I was the only who tried to speak English in the } \\
\text { classroom }\end{array}$ \\
\hline $\begin{array}{l}\text { Difficulty in } \\
\text { understanding }\end{array}$ & $\begin{array}{l}\text { Not being able to } \\
\text { understand when } \\
\text { teacher speaks } \\
\text { English }\end{array}$ & $\begin{array}{l}\text { Includes speaking English in } \\
\text { the classroom } \\
\text { Excludes speaking Turkish in } \\
\text { the classroom }\end{array}$ & $\begin{array}{l}\text { p. } 3 \text {...it would be hard for them (students) to } \\
\text { understand sentences, words }\end{array}$ \\
\hline $\begin{array}{l}\text { Tip of the } \\
\text { tongue }\end{array}$ & $\begin{array}{l}\text { When teacher does } \\
\text { not remember a } \\
\text { translation equivalent }\end{array}$ & $\begin{array}{l}\text { Includes English words } \\
\text { Excludes Turkish words }\end{array}$ & $\begin{array}{l}\text { p. } 6 \text { Even in tip of tongue moment, they would swallow } \\
\text { it back and say in English }\end{array}$ \\
\hline $\begin{array}{l}\text { Emphasize a } \\
\text { point }\end{array}$ & $\begin{array}{l}\text { A reason that teacher } \\
\text { code-switched }\end{array}$ & $\begin{array}{l}\text { Includes code-switching (CS) } \\
\text { from English to Turkish (E->T) } \\
\text { Excludes CS from Turkish to } \\
\text { English (T->E) }\end{array}$ & $\begin{array}{l}\text { p. } 6 \text { I think they always } C S \text { when they want to } \\
\text { emphasize a point. }\end{array}$ \\
\hline Slip of tongue & $\begin{array}{l}\text { Code-switching is a } \\
\text { kind of slip of tongue }\end{array}$ & $\begin{array}{l}\text { Includes CS E->T } \\
\text { Excludes CS T->E }\end{array}$ & $\begin{array}{l}\text { p. } 7 \text { In situations like I proposed previously, I think it } \\
\text { more falls to the situation of slip of tongue instead of } \\
\text { something deliberate. }\end{array}$ \\
\hline
\end{tabular}




\begin{tabular}{|c|c|c|c|}
\hline $\begin{array}{l}\text { Lack of } \\
\text { Faculty }\end{array}$ & $\begin{array}{l}\text { A reason why } \\
\text { someone } \\
\text { code-switches }\end{array}$ & $\begin{array}{l}\text { Includes CS E->T } \\
\text { Excludes CS T->E }\end{array}$ & $\begin{array}{l}\text { p. } 7 \text { Actually one of the reasons for CS is lack of } \\
\text { faculty. }\end{array}$ \\
\hline $\begin{array}{l}\text { Lack of } \\
\text { register }\end{array}$ & $\begin{array}{l}\text { A reason why } \\
\text { someone } \\
\text { code-switches }\end{array}$ & $\begin{array}{l}\text { Includes CS T- }>\text { E } \\
\text { Excludes CS E->T }\end{array}$ & $\begin{array}{l}\text { p. } 8 \text { Let's say in daily life when I talk to my peers in } \\
\text { Turkish...we use terms from linguistics class like } \\
\text { performance or competence. We do not translate these } \\
\text { terms to Turkish.... One of the reasons is lack of register. }\end{array}$ \\
\hline $\begin{array}{l}\text { The master of } \\
\text { the language }\end{array}$ & $\begin{array}{l}\text { To be proficient in } \\
\text { the language }\end{array}$ & $\begin{array}{l}\text { Includes English } \\
\text { Excludes Turkish }\end{array}$ & $\begin{array}{l}\text { p. } 9 \text { It would suggest the lack of faculty. That (CS) is } \\
\text { not good for an English teacher. I am supposed to be } \\
\text { the master of the language. }\end{array}$ \\
\hline $\begin{array}{l}\text { The ideal } \\
\text { teacher }\end{array}$ & A good teacher & $\begin{array}{l}\text { Includes English teachers } \\
\text { Excludes teachers of other } \\
\text { subjects }\end{array}$ & $\begin{array}{l}\text { p. } 10 \text { I think the use of Turkish affects my } \\
\text { perceptions. The teacher in my mind, the ideal } \\
\text { teacher becomes a more relaxed person. }\end{array}$ \\
\hline
\end{tabular}

\section{APPENDIX E: The Codebook of the Whole Data}

\begin{tabular}{|c|c|c|c|}
\hline Code & Definition & $\begin{array}{l}\text { Inclusion/Exclusion } \\
\text { Criteria }\end{array}$ & Example from the Text \\
\hline $\begin{array}{l}\text { Classroom as } \\
\text { the only place to } \\
\text { practice English }\end{array}$ & $\begin{array}{l}\text { When these pre-service } \\
\text { teachers were EFL } \\
\text { students, they could } \\
\text { practice English only } \\
\text { in the classroom }\end{array}$ & $\begin{array}{l}\text { Includes EFL setting } \\
\text { Excludes ELT settings }\end{array}$ & $\begin{array}{l}\mathrm{N}, \text { I didn't have any opportunity to practice } \\
\text { English out of my classroom. }\end{array}$ \\
\hline $\begin{array}{l}\text { Language choice in } \\
\text { EFL classrooms }\end{array}$ & $\begin{array}{l}\text { It refers to the } \\
\text { language used by their } \\
\text { teachers when the } \\
\text { interviewees were EFL } \\
\text { students }\end{array}$ & $\begin{array}{l}\text { Includes EFL setting } \\
\text { Excludes ELT settings }\end{array}$ & $\begin{array}{l}\mathrm{E}, \text { In my time they used their mother tongue in } \\
\text { the classroom as well, especially explaining } \\
\text { some certain information about lesson. }\end{array}$ \\
\hline $\begin{array}{l}\text { Oral use of English } \\
\text { in the classroom }\end{array}$ & $\begin{array}{l}\text { It refers to learning } \\
\text { background of } \\
\text { interviewees when } \\
\text { they were EFL } \\
\text { students }\end{array}$ & $\begin{array}{l}\text { Includes ELT } \\
\text { Excludes EFL }\end{array}$ & $\begin{array}{l}\mathrm{N}, \ldots \text { there were native speakers. We could talk } \\
\text { to them in English. We made practice orally. } \\
\mathrm{E}, \text { There were role-pays in the classroom. We } \\
\text { acted as an actress or actor. Or we worked as a } \\
\text { group, se we used English in this way. }\end{array}$ \\
\hline $\begin{array}{l}\text { Reason-emphasizing } \\
\text { a point }\end{array}$ & $\begin{array}{l}\text { A reason that teacher } \\
\text { code-switches in the } \\
\text { classroom }\end{array}$ & $\begin{array}{l}\text { Includes code-switching } \\
\text { (CS) from English to } \\
\text { Turkish (E->T) } \\
\text { Excludes CS from } \\
\text { Turkish to English (T->E) }\end{array}$ & $\begin{array}{l}\text { M, p. } 6 \text { I think they always CS when they want } \\
\text { to emphasize a point. }\end{array}$ \\
\hline $\begin{array}{l}\text { Reason "Slip of } \\
\text { tongue" }\end{array}$ & $\begin{array}{l}\text { One of the reasons } \\
\text { when the teacher } \\
\text { code-switches in } \\
\text { language classroom }\end{array}$ & $\begin{array}{l}\text { Includes CS E->T } \\
\text { Excludes CS T->E }\end{array}$ & $\begin{array}{l}\text { M, p. } 7 \text { In situations like I proposed previously, } \\
\text { I think it more falls to the situation of slip of } \\
\text { tongue instead of something deliberate. }\end{array}$ \\
\hline $\begin{array}{l}\text { Reason- lack of } \\
\text { proficiency }\end{array}$ & $\begin{array}{l}\text { The teacher } \\
\text { code-switches if she/ } \\
\text { he is not proficient } \\
\text { enough in a foreign } \\
\text { language }\end{array}$ & $\begin{array}{l}\text { Includes CS E->T } \\
\text { and EFL and ELT } \\
\text { classrooms } \\
\text { Excludes CS T->E and } \\
\text { other settings }\end{array}$ & $\begin{array}{l}\text { M, p. } 7 \text { Actually one of the reasons for CS is } \\
\text { lack of faculty. }\end{array}$ \\
\hline $\begin{array}{l}\text { Reason- making } \\
\text { students understand }\end{array}$ & $\begin{array}{l}\text { The teacher } \\
\text { code-switches when } \\
\text { students do not } \\
\text { understand }\end{array}$ & $\begin{array}{l}\text { Includes CS E->T and } \\
\text { EFL-ELT classrooms } \\
\text { Excludes CS T->E and } \\
\text { other settings }\end{array}$ & $\begin{array}{l}\text { N, p. } 4 \text { Second, the students cannot understand } \\
\text { and maybe the lecturer wants to make points } \\
\text { clear. }\end{array}$ \\
\hline $\begin{array}{l}\text { Feeling-neutrality } \\
\text { towards CS }\end{array}$ & $\begin{array}{l}\mathrm{N} \text { has neutral feelings } \\
\text { towards CS in the } \\
\text { classroom }\end{array}$ & $\begin{array}{l}\text { Includes CS E->T and } \\
\text { classroom setting } \\
\text { Excludes CS T->E and } \\
\text { other settings }\end{array}$ & $\begin{array}{l}\text { N, p. } 4 \text { I don't think it is so much importance } \\
\text { when they sometimes introduce Turkish in an } \\
\text { English sentence. They can do that. I don't think } \\
\text { something negative or positive. I am neutral. }\end{array}$ \\
\hline Feeling-relief & $\begin{array}{l}\text { E feels relieved } \\
\text { when the teacher } \\
\text { code-switches }\end{array}$ & $\begin{array}{l}\text { Includes CS E->T and } \\
\text { classroom setting } \\
\text { Excludes CS T->E other } \\
\text { settings }\end{array}$ & $\begin{array}{l}\text { E, p. } 4 \text { When they code switch I feel relieved } \\
\text { in some issues...For example in literature } \\
\text { classroom, teacher code-switches about a } \\
\text { literary term... }\end{array}$ \\
\hline
\end{tabular}




\begin{tabular}{|c|c|c|c|}
\hline $\begin{array}{l}\text { Avoiding excessive } \\
\text { use of CS }\end{array}$ & $\begin{array}{l}\text { Both } \mathrm{N} \text { and } \mathrm{E} \text { think } \\
\text { that } \mathrm{CS} \text { should not be } \\
\text { used excessively }\end{array}$ & $\begin{array}{l}\text { Includes CS E->T and } \\
\text { classroom setting } \\
\text { Excludes CS T->E other } \\
\text { settings }\end{array}$ & $\begin{array}{l}\mathrm{E}, \mathrm{p} . \text { If they (teachers) often use CS, students } \\
\text { may think that we don't understand anything } \\
\text { and he always CS...I mean students feel lazy or } \\
\text { idiot. }\end{array}$ \\
\hline $\begin{array}{l}\text { The effect of } \\
\text { language use by the } \\
\text { professor }\end{array}$ & $\begin{array}{l}\text { The professors and } \\
\text { their language use in } \\
\text { the classroom affects } \\
\text { students' views }\end{array}$ & $\begin{array}{l}\text { Includes ELT classrooms; } \\
\text { ELT professors that } \\
\text { have taught them at the } \\
\text { university } \\
\text { Excludes EFL classrooms } \\
\text { and other professors }\end{array}$ & $\begin{array}{l}\mathrm{E}, \text {...it affects me when I see a lecturer code } \\
\text { switch, there is no problem. I can use it as well. } \\
\mathrm{N}, \text { You know we idealize our lecturers at the } \\
\text { university, because it is the last step before we } \\
\text { become a teacher. }\end{array}$ \\
\hline $\begin{array}{l}\text { Who is an English } \\
\text { teacher? }\end{array}$ & $\begin{array}{l}\text { It refers to three } \\
\text { pre-service teachers' } \\
\text { perception about who } \\
\text { an English teacher is. }\end{array}$ & $\begin{array}{l}\text { Includes English language } \\
\text { teachers } \\
\text { Excludes other teaching } \\
\text { majors }\end{array}$ & $\begin{array}{l}\text { M, Teaching is not really an easy thing. So first } \\
\text { you have to master English... you also have to } \\
\text { take courses and make research on your own } \\
\text { let's say pedagogy about how to teach. } \\
N \text {, is not the one who just knows the language. } \\
\text { He needs to know the culture, pragmatic } \\
\text { knowledge.when to use what.our material is } \\
\text { language, so we use it to communicate. So the } \\
\text { teacher has to have good communicative skills } \\
\text { besides having English language knowledge. }\end{array}$ \\
\hline $\begin{array}{l}\text { Self-perception as } \\
\text { an (pre-service) } \\
\text { English teacher }\end{array}$ & $\begin{array}{l}\text { It refers to three } \\
\text { pre-service teachers' } \\
\text { self perceptions as } \\
\text { English teachers }\end{array}$ & $\begin{array}{l}\text { Includes both their } \\
\text { practices as pre-service } \\
\text { teachers and the English } \\
\text { teacher they would like } \\
\text { to be } \\
\text { Excludes other English } \\
\text { teachers. }\end{array}$ & $\begin{array}{l}\text { E, ... When I become a teacher in the future, } \\
\text { maybe I want the students ask questions all } \\
\text { the time, they should be incurious. . to make } \\
\text { lessons interactive, I make them groups, I try } \\
\text { to make them interact, to interact each other } \\
\text { by using groups works, pair works, or dramas. }\end{array}$ \\
\hline
\end{tabular}

\section{APPENDIX F: Interview Protocol Form}

Suna Altun

Advanced Qualitative Research Methods

24.02.2016

Research Questions-Interview Protocol- Graphic Elicitation

\section{Research Questions}

1. What are the perceptions of pre-service teachers about the code-switching by their professors?

2. ???

3. How do the perceptions of pre-service ELT teachers about code-switching affect the process of their identity formation as a teacher?

\section{Interview Protocol}

Welcome and thank you for your participation in this interview. My name is Suna Altun and I am a PhD student at Yeditepe University conducting a research in the scope of Qualitative Research Methods course. The research is about the perceptions of pre-service ELT teachers about code-switching. Thank you for being voluntary to answer the questions. The interview will take about 45 minutes and will include 10 questions regarding your experiences and feelings. I would like your permission to tape record this interview, so I will be able to document the information you convey accurately. If at any time during the interview you wish to stop the use of the recorder or the interview itself, please feel free to ask. All of your responses are confidential.

At this time I would like to remind you of your written consent to participate in this study. I am the responsible investigator, specifying your participation in the research project: Perceptions of pre-service ELT teachers about code-switching. You and I have both signed and dated each copy, certifying that we agree to continue this interview. You will receive one copy and I will receive the other copy.

Your participation in this interview is completely voluntary. If at any time you need to stop or take a break please let me know. You may also withdraw your participation at any time without consequence. Do you have any questions or concerns before we begin? If you don't have, with your permission we will begin the interview. 
The details of this study were explained to me by:

Investigator Name:

Date:

I have read the above project description. I agree with the terms and hereby consent to participate in the study.

Participant Signature:

Participant Name (please print):

$\chi$ I certify that I am over 18 years of age.

Date:

\section{Questions}

1. Where did you learn English? Have you had any opportunities to practice English orally out of classroom in your school years? How did you use English orally in classroom?

2. What language did your English teachers use before you started ELT program in the classroom? Did he/she ever mix languages (English and Turkish)? How did it affect you oral English performance?

3. What language do you think your lecturer should use in ELT courses? Why?

4. What is the language of instruction in your English Language Teaching (ELT) courses currently?

5. How would you feel when/if the lecturer code-switches (between English and Turkish) in ELT classes?

6. Can you suggest some reasons for which you think that a lecturer code-switches in the classroom?

7. What language do you think an English teacher should use in English as Foreign Language (EFL) classroom? What language do you use while teaching?

8. What would be the reasons if you code-switch while teaching English?

9. What perceptions do you think you and your students may have if you code-switch while teaching?

10. How do you think code-switching by your lecturers in ELT classrooms affects your identity development as a pre-service teacher?

11. Who is an English teacher? Can you define an English teacher?

12. Define speaking skills of your lecturer; yourself, and the one who you would like to be.

\section{APPENDIX G: Graphic elicitation Protocol Form}

\section{Graphic Elicitation Prompt}

1. Use the space below and draw how you feel when your lecturer switches between the languages in your ELT courses.

2. Use the space below and draw yourself as an English teacher and importance of language choice in English classes. 